\title{
Intersyngenic Variations in the Esterases of Axenic Stocks of Paramecium aurelia
}

\author{
Sally Lyman Allen ${ }^{1}$ and Ian Gibson ${ }^{2}$
}

Received 15 July 1970-Final 12 Nov. 1970

The esterase isozymes were surveyed in axenic stocks of syngens 1,2, 4, 5, 6, and 8 of Paramecium aurelia by starch gel electrophoresis. In paramecia there appear to be four types of esterases which are clearer in axenic than in bacterized stocks. Each type differs in its substrate specificity and/or its response to the inhibitor eserine sulfate. Minor variations in type $D$ esterases sometimes occur in different extracts of the same stock and may result from changes in the temperature of growth of the cells or growth cycle differences. Differences in the mobility of the $A, B$, or $C$ (cathodal) types of esterasesmay occur in different syngens. They also occur for the $A$ and $B$ types among stocks within a syngen, but the frequency is low, except in the case of syngen 2. Since each of the types of esterases varies independently, at least four and possibly more genes appear to specify the esterases in the species complex. Some pairs of syngens vary in their electrophoretic positions for all types of esterases. Other pairs have identical zymograms. This observation suggests that some syngens may differ from each other by as many as four esterase genes, while others may not differ at all. The difference between P. aurelia and Tetrahymena pyriformis in the degree of intrasyngenic variation observed for enzymes is discussed in relation to other types of characters, the organization of the genetic material in the macronucleus, the presence of symbionts, and their breeding systems. It is suggested that enzyme variation is achieved by the action of different selective forces in these two groups of ciliated protozoa.

\section{INTRODUCTION}

Paramecium aurelia is a species complex which is subdivided into a number of breeding groups called syngens (Sonneborn, 1957). Gene flow does not occur between syngens. We have been concerned with isozyme variation within and among syngens and the ordering of differences in terms of evolutionary relationships.

\footnotetext{
Supported by research grants from the National Institute of General Medical Sciences (GM-15879), U.S. Public Health Service, and from the British Medical Research Council.

${ }^{1}$ Departments of Botany and Zoology, The University of Michigan, Ann Arbor, Michigan.

${ }^{2}$ School of Biological Sciences, University of East Anglia, Norwich, England.
} 
Paramecia can be grown either on bacteria or under axenic conditions in a medium free of bacteria (Soldo et al., 1966). When the esterases of bacterized stocks were surveyed, some of the variations could be ordered with respect to syngen differences (Allen et al., 1971), but other variations appear to be contributed by the bacteria

Table I. Axenic Stocks of $P$. aurelia

\begin{tabular}{|c|c|c|c|}
\hline Syngen & Stock No. & Geographic origin & Source \\
\hline \multirow[t]{13}{*}{1} & $\mathrm{P}$ & Maryland & University of East Anglia (UEA) \\
\hline & 33 & Maryland & UEA \\
\hline & 60 & Virginia & UEA \\
\hline & 90 & Pennsylvania & UEA, Hairston ${ }^{a}$ \\
\hline & 143 & Scotland & UEA \\
\hline & 168 & Japan & UEA \\
\hline & 171 & Japan & UEA \\
\hline & 180 & Japan & UEA \\
\hline & 513 & France & UEA \\
\hline & 540 & Mexico & UEA \\
\hline & 544 & Louisiana & UEA \\
\hline & 548 & California & UEA, van Wagtendonk \\
\hline & 551 & California & UEA, van Wagtendonk \\
\hline \multirow[t]{8}{*}{2} & 7 & North Carolina & UEA \\
\hline & 35 & Connecticut & Indiana $^{a}$ \\
\hline & 50 & Oregon & Indiana $^{a}$ \\
\hline & 93 & Pennsylvania & Hairston $^{a}$ \\
\hline & 114 & Indiana & UEA \\
\hline & 305 & Arizona & Indiana $^{a}$ \\
\hline & 562 & Italy & UEA \\
\hline & $\mathrm{He}-2$ & England & UEA \\
\hline \multirow[t]{4}{*}{4} & 29 & Maryland & Hairston $^{a}$ \\
\hline & $51-\mathrm{kappa}^{b}$ & Indiana & van Wagtendonk \\
\hline & 51 & Indiana & van Wagtendonk \\
\hline & 139-pi & Florida & van Wagtendonk \\
\hline \multirow[t]{3}{*}{5} & 76 & New Jersey & Hairston $^{a}$ \\
\hline & $87-\mathrm{nu}$ & Pennsylvania & van Wagtendonk \\
\hline & 107 & Pennsylvania & Indiana $a^{a}$ \\
\hline \multirow[t]{2}{*}{6} & 101 & Pennsylvania & van Wagtendonk \\
\hline & 225-delta & Florida & van Wagtendonk \\
\hline \multirow[t]{9}{*}{8} & 31 & Maryland & van Wagtendonk \\
\hline & 130 & Florida & UEA \\
\hline & 131 & Florida & UEA \\
\hline & 137 & Florida & UEA \\
\hline & 138-mu & Florida & UEA, van Wagtendonk \\
\hline & 229-lambda & Florida & van Wagtendonk \\
\hline & 299-lambda & Panama & van Wagtendonk \\
\hline & 299 & Panama & UEA, van Wagtendonk \\
\hline & 327-lambda & Florida & van Wagtendonk \\
\hline
\end{tabular}

${ }^{a}$ Bacterized stocks were rendered axenic at Michigan by use of TREE (described in van Wagtendonk et al., 1970) and handwashing using the antibiotic Neamine (a gift of the Upjohn Company, Kalamazoo, Mich.). The UEA stocks were rendered axenic by the method described in Rowe et al. (1971).

b Greek letter denotes type of bacterial symbiont carried by stock. 
(Rowe et al., 1971). Since complications are introduced by the use of bacterized stocks, a survey of axenic stocks in different syngens was carried out.

In this paper, we report our observations on syngens $1,2,4,5,6$, and 8 . Eventually we hope to extend our survey to stocks from all 14 syngens.

We examined the following questions: (a) What is the degree of intrasyngenic and intersyngenic variation in axenic stocks? (b) Can these variations be ordered with respect to syngen relationships? (c) And how does this compare to the ordering obtained with bacterized stocks? We were also interested in comparing the observations made so far on $P$. aurelia with those of Tetrahymena pyriformis (Allen and Weremiuk, 1971). In $T$. pyriformis there is a high degree of enzyme polymorphism within a syngen, whereas in $P$. aurelia it is usually very low. Why?

\section{MATERIALS AND METHODS}

\section{Stocks}

In most of this study, stocks growing on axenic medium (Soldo et al., 1966) were used. These are listed in Table I along with their geographic origin. The axenic stocks were maintained in tube culture at $23 \mathrm{C}$ (University of Michigan) or $27 \mathrm{C}$ (University of East Anglia) by subculturing at 7-12 days.

Samples of these stocks were also maintained in bacterized medium (at Michigan in Cerophyl rye grass inoculated with Aerobacter aerogenes).

\section{Growth of Cells for Extracts}

One-liter axenic cultures of paramecia grown at $27 \mathrm{C}$ were obtained as previously described (Rowe et al., 1971). At Michigan, such cultures were obtained by adding a cleared flask culture containing $100 \mathrm{ml}$ of cells to $900 \mathrm{ml}$ of axenic medium in 2-liter Povitsky bottles with growth at $23 \mathrm{C}$ for 5-7 days.

One-liter bacterized cultures were obtained as described (Allen et al., 1971) except that growth of the cells occurred at $23 \mathrm{C}$.

The cells were concentrated in an oil-testing centrifuge in pear-shaped tubes, washed once with Dryl's solution (Dryl, 1959), and further concentrated in a clinical centrifuge in conical centrifuge tubes. Cell packs varied from 0.3 to $3.0 \mathrm{ml} /$ liter depending upon the axenic stock. Smaller volumes were obtained from bacterized cultures. The cells were disrupted by freeze-thawing, and the extracts were stored at $-20 \mathrm{C}$ until the day of use.

In this study, frozen extracts of axenic stocks and freshly prepared bacterized stocks (grown at Michigan) were used as well as extracts of bacterized stocks (grown at Indiana University) which had been stored at $-20 \mathrm{C}$ for $1 \frac{1}{2}-2$ years.

\section{Electrophoretic Procedure}

Starch gel electrophoresis was carried out as previously described (Allen et al., 1971; Rowe et al., 1971). In these experiments, $12 \%$ gels were used as well as different lots of starch, and the length of electrophoresis varied from 4 to $5 \mathrm{hr}$. Slight variations in the 
$p \mathrm{H}$ of the electrode buffer $(p \mathrm{H} \mathrm{7.45-7.55)}$ are responsible for minor differences in the separations.

\section{Identification of Esterases}

For most experiments, the two substrates $\alpha$-naphthyl propionate and $\alpha$-naphthyl butyrate were used in the manner previously described (Allen et al., 1971; Rowe et al., 1971). In some experiments, $\alpha$-naphthyl acetate was used. Sodium taurocholate was not included in any of the incubation mixtures since it was found to have no effect on Paramecium esterases.

In some experiments, inhibitors (or potential activators) were used. Experimental gels were preincubated for $30 \mathrm{~min}$ in buffer containing the inhibitor, control gels in buffer alone. These solutions were poured off and replaced with the incubation medium. For experimental gels, the incubation medium also contained the inhibitor.

The inhibitors used were sodium taurocholate $\left(10^{-2} \mathrm{M}\right), p$-chloromercuribenzoic acid $\left(10^{-3} \mathrm{M}\right)$, and eserine sulfate at four concentrations $\left(10^{-1}, 10^{-2}, 10^{-3}\right.$, and $\left.10^{-4} \mathrm{M}\right)$.

The gels were incubated for $2-4 \mathrm{hr}$ at $30 \mathrm{C}$, rinsed with distilled water, and stored in $7 \frac{1}{2} \%$ acetic acid until photographed.

\section{RESULTS}

\section{Comparison of Axenic and Bacterized Stocks}

The esterases of bacterized stocks were arbitrarily classified into four types on the basis of substrate specificity (Allen et al., 1971). Type A splits only $\alpha$-naphthyl propionate, type B splits $\alpha$-naphthyl butyrate more efficiently than $\alpha$-naphthyl propionate, type $C$ splits propionate more rapidly than butyrate, and type $\mathrm{D}$ splits both substrates to the same extent. Despite the presence of bacterial esterases (types B-D), major variations of Paramecium esterases of types $\mathrm{A}, \mathrm{B}$, and $\mathrm{C}$ could be recognized.

The major classes of Paramecium esterases are also present in axenically grown cells. There are, however, additional esterases, some of which are weak and others which are sporadic in their appearance in different preparations of the same stock. These are of types C and D. The "axenic" esterase described in the preceding paper (Rowe et al., 1971) is a type D esterase.

Figure 1 compares axenically grown stocks with bacterized stocks grown at Indiana University from syngens $1,2,4,5,6$, and 8 . Where possible, the same stock was used in the comparison. There are more esterases in the zymograms of the Indiana stocks, but the major classes are recognizable. The A esterases are more active, particularly in the more anodal position (syngens $1,4,5,6,8$ ). A third A esterase seems to occur in syngens $1,4,5$, and 8 , although it may be superimposed over other types of esterases within the same region. Thus, it is possible that the A esterases may be more active in bacterized than in axenic stocks. The other types of esterases (B and C) are usually as active in axenic as in the Indiana-grown stocks. In general, we have observed that when a stock is taken from bacterized growth conditions and placed in axenic medium, some esterases may disappear, new esterases may appear, some may be intensified, and others may be reduced in activity. 


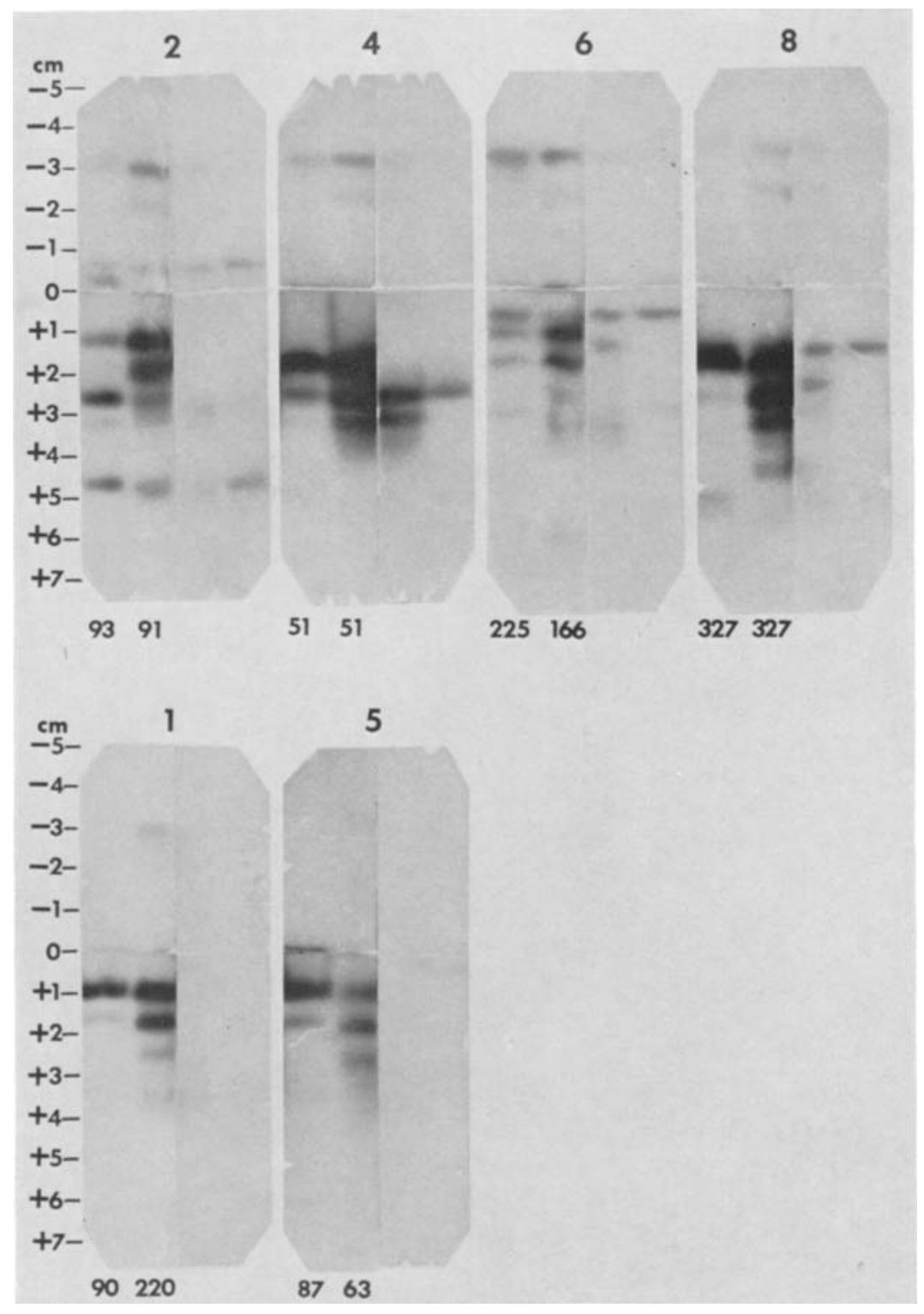

Fig. 1. Comparison of axenic and bacterized Indiana stocks from different syngens. Top: even syngens $(2,4,6,8)$. Bottom: odd syngens $(1,5)$. See Allen et al. (1971) for information on Indiana stocks $91,166,220$, and 63 . Gel on left was incubated in $\alpha$-naphthyl propionate, gel on right with $\alpha$-naphthyl butyrate. Axenic stocks are on left, bacterized stocks on right side of gel incubated in $\alpha$-naphthyl propionate (positions reversed with $\alpha$-naphthyl butyrate). Note additional $A$ esterases in all bacterized stocks and additional B esterases in bacterized stocks of syngens 4,6 , and 8 . Distances in migration are marked off in centimeters from the origin on the margin(s) of the photographs. Electrophoresis was carried out for $4 \mathrm{hr}$. 
$\mathrm{cm}$

$-5-$

$-4-$

$-3-$

$-2-$

$-1-$

o-

$+1-$

$+2-$

$+3-$

$+4-$

$+5-$

$+6-$

$+7-$

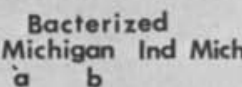

a

$$
\begin{aligned}
& -5- \\
& -4- \\
& -3- \\
& -2- \\
& -1- \\
& 0- \\
& +1- \\
& +2- \\
& +3- \\
& +4- \\
& +5- \\
& +6- \\
& +7
\end{aligned}
$$

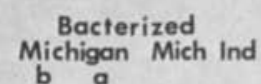

90
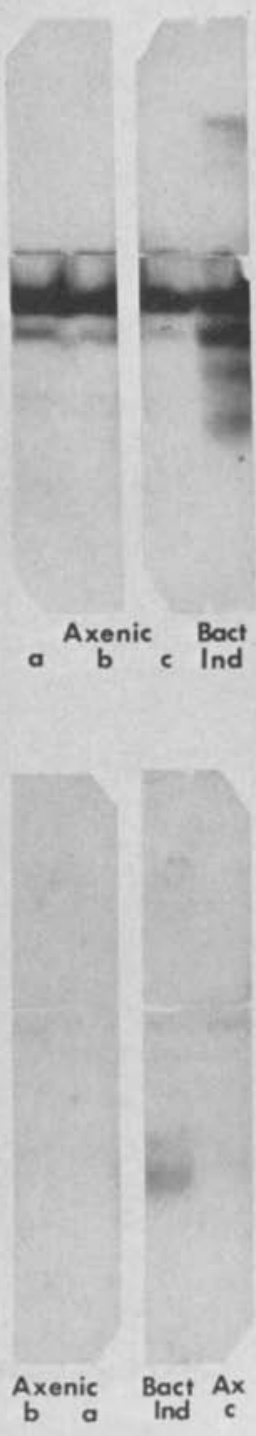
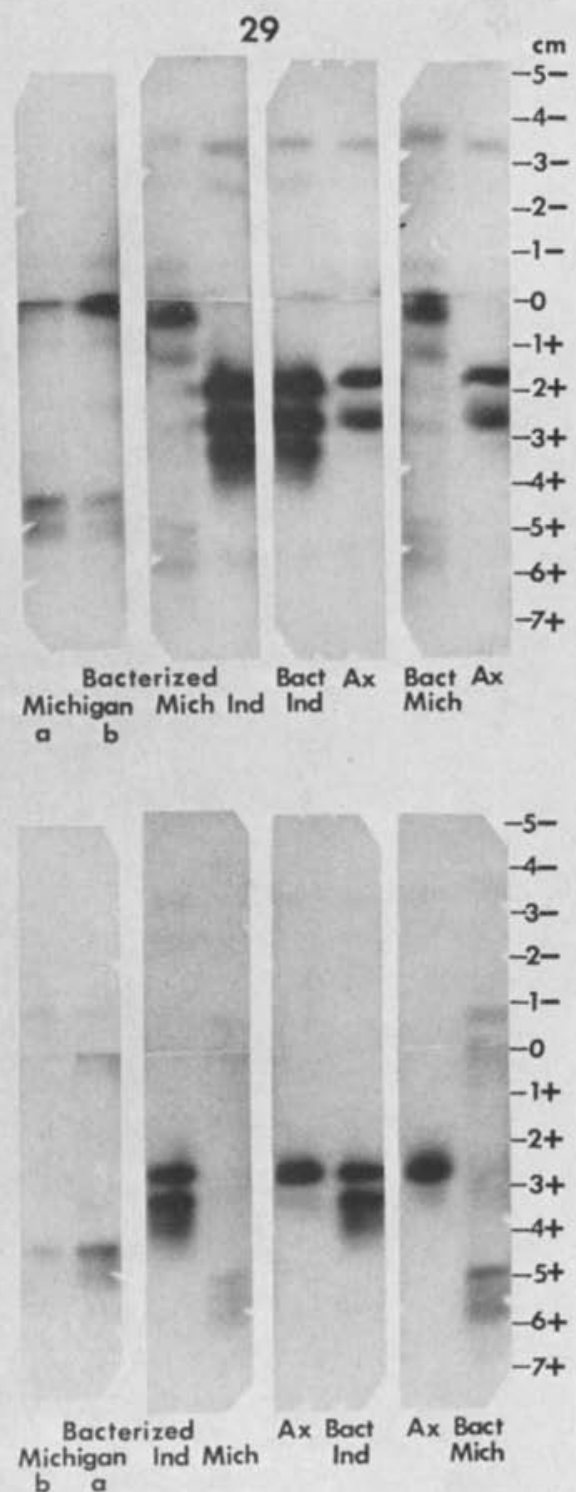

Fig. 2. Comparison of stocks 90 and 29 under three conditions of growth-axenic (ax), bacterized Indiana (Bact Ind), and bacterized Michigan (Bact Mich). In comparisons with 90, note that stock $320 /$ syngen 1 was used for the bacterized Indiana stock. Top eight gels were incubated in $\alpha$-naphthyl propionate, bottom eight gels in $\alpha$-naphthyl butyrate. Michigan a = extract of cells grown for 3 days, Michigan $b=4$-day extract. Axenic $a=$ extract of cells grown 3 days, Axenic $b=5$-day extract, Axenic $\mathrm{c}=6$-day extract. Slight differences in migration are due to slight differences in $p \mathrm{H}$ of electrode buffer in different electrophoretic runs (i.e., 29 gel on left vs. other three gels). Electrophoresis was carried out for $4 \mathrm{hr}$. 
Esterases specific to Paramecium are recognizable in the Indiana bacterized stocks. However, under other conditions of growth in bacteria, they are not recognizable. Indeed, syngen differences may even be obliterated. This is illustrated in Fig. 2, where stock 90/syngen 1 and stock 29/syngen 4 are compared with respect to cells grown axenically and cells grown on bacteria at Indiana University and at the University of Michigan. The latter stocks were obtained from Dr. Nelson Hairston, who had maintained them at Michigan in Cerophyl rye grass inoculated with $A$. aerogenes some 11 years since receiving them from Indiana. The esterases of the bacterized Michigan stocks depart widely from the bacterized Indiana stocks, and there are even differences among extracts made on different days. Yet, when the Michigan stocks were rendered bacteria free and placed into axenic medium, the Paramecium-specific esterases became manifest. The Michigan bacterized stocks apparently carry many bacterial contaminants since preparations of $A$. aerogenes at Michigan have only a single esterase, type $C$ in character, which migrates between $+6-7 \mathrm{~cm}$ in $4 \mathrm{hr}$. These contaminants might affect the synthesis of the Paramecium esterases. More likely, their presence results in obliteration of the Paramecium esterases by diluting out their activity in the extracts.

\section{Esterases of Axenic Stocks}

The esterases of axenic stocks are diagrammed in Fig. 3. The major types of esterases (types A, B, and cathodal C) appear to be unaffected by the conditions under which

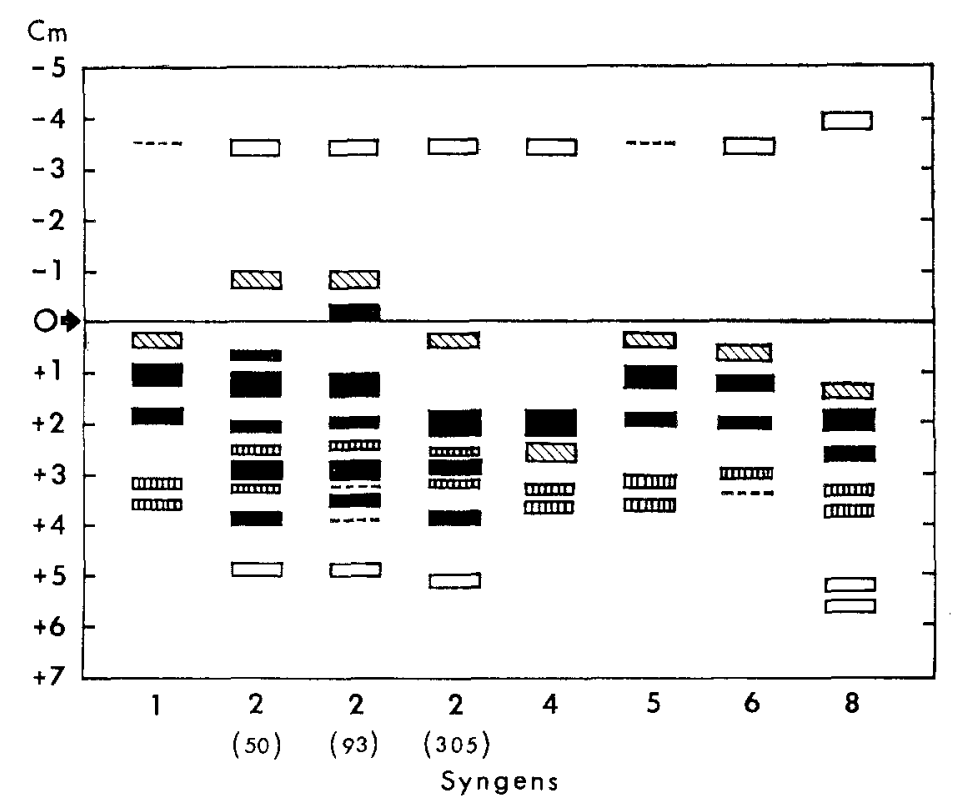

Fig. 3. Diagram of esterases in axenic stocks in different syngens drawn from gels in which electrophoresis was carried out for $4 \mathrm{hr}$. Types of esterases are represented by the following symbols: $\mathbf{a}-\mathrm{A}$ type, $\square-\mathrm{B}$ type, $\square-\mathrm{C}$ type, and $\square-\mathrm{D}$ type. 

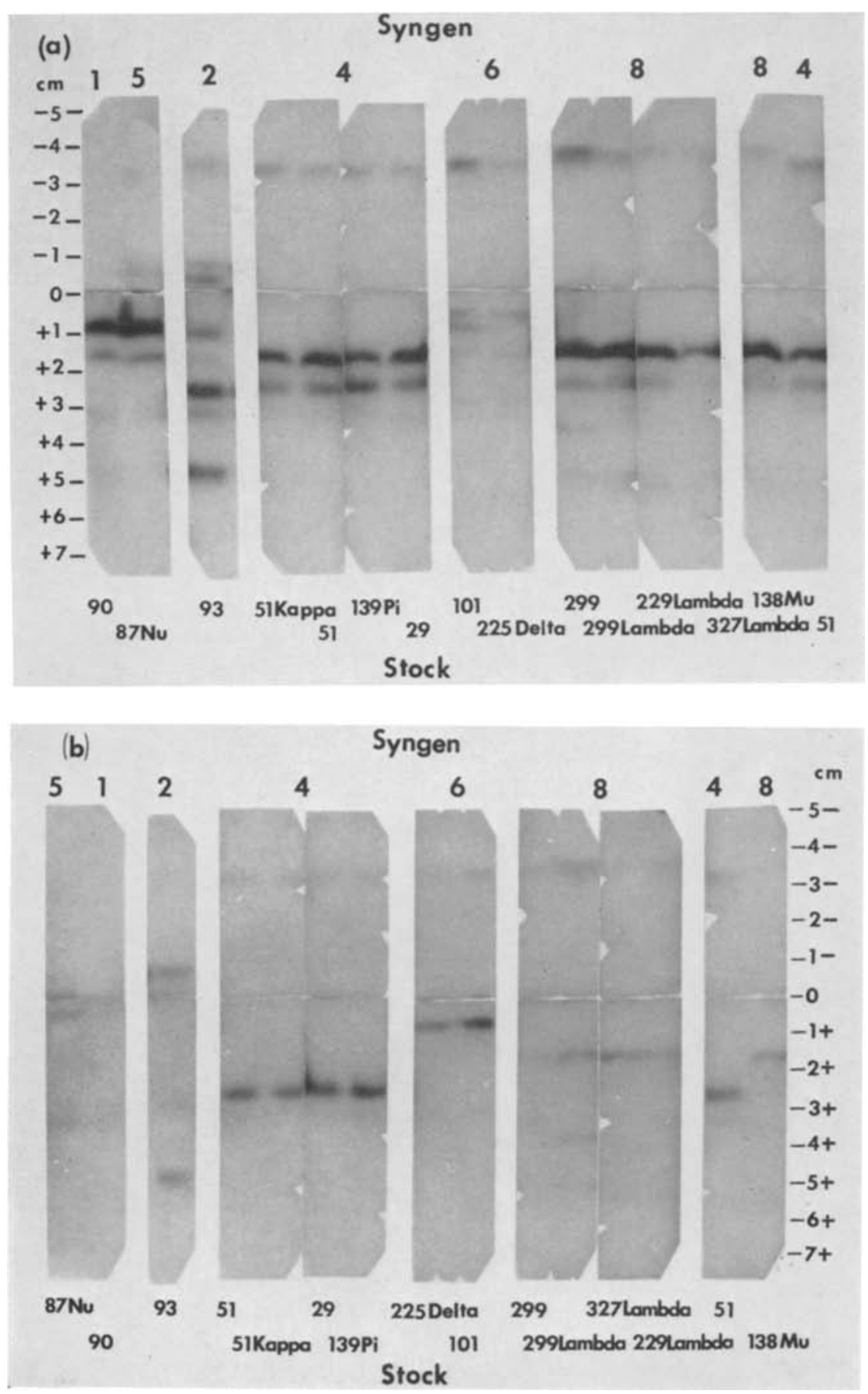

Fig. 4. (a) Esterases of representative axenic stocks from syngens 1, 2, 4, 5, 6, and 8 . Substrate: $\alpha$-naphthyl propionate. (b) Same stocks as in (a) but substrate is $\alpha$-naphthyl butyrate. Electrophoresis was carried out for $4 \mathrm{hr}$ in (a) and (b). (c) Esterases of variant stocks in syngens 1 and 8 . Electrophoresis was carried out for 5 hr. 


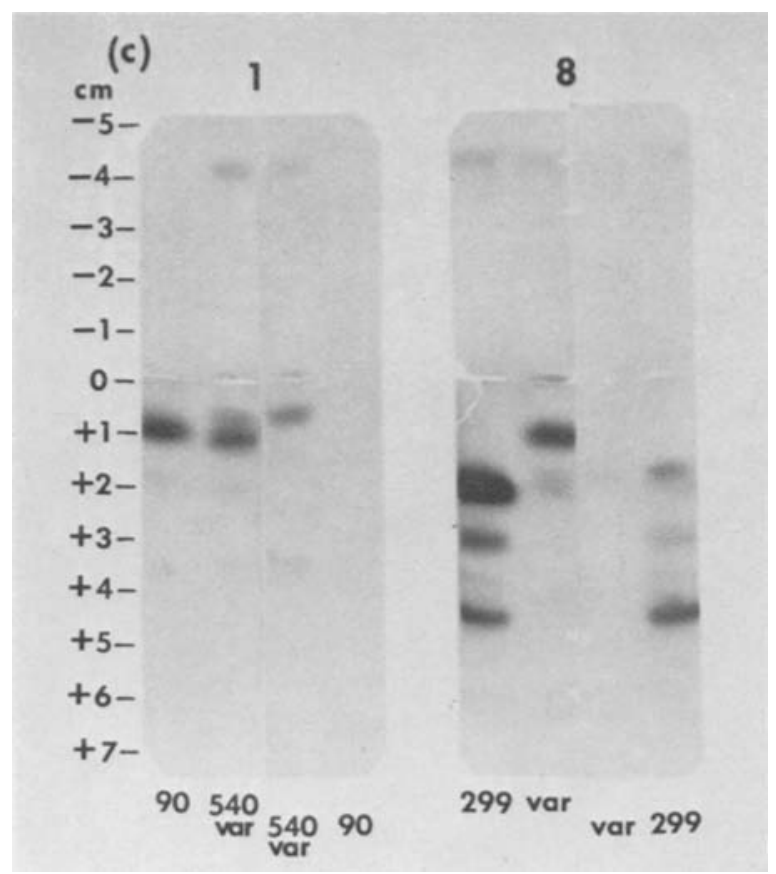

Fig. 4 (continued).

the cells are grown. This is not so for other esterases, such as the type D esterases found in a region $+3-4 \mathrm{~cm}$ after $4 \mathrm{hr}$ of electrophoresis. These esterases seem to vary in different preparations, particularly from cells grown at different temperatures. The nature of these variations is not yet understood. It could be a temperature response, but it may also reflect growth cycle differences. Significantly, these esterases are found in the same region as the "axenic" esterase reported by Rowe et al. (1971) in stock 540.

Only a limited number of stocks within a single syngen have been surveyed so far. The minimum number examined has been two. The largest number is 13 in syngen 1 . The data for representative stocks from all six syngens are shown in Fig. 4a,b, for some syngen 2 stocks in Fig. 5A,B, and for some syngen 8 stocks in Fig. 6. Major variations were observed among stocks infrequently, except for syngen 2. Stock 540 in syngen 1 has a variant $B$ esterase with the mobility of that found in syngen 6 (Fig. 4c). One branch of stock 299 in syngen 8 has variant A esterases with mobilities similar to those found in syngens 1 and 5 (the other branch of stock 299 has A esterases typical of syngen 8; see Fig. 4c). A second variant A esterase pattern occurs in stock 137 (see Fig. 6). It has typical syngen $8 \mathrm{~B}$ and $\mathrm{C}$ esterases. Although variations occur in both the $A$ and $B$ types of esterases in syngen 2 , the greatest amount of variation involves the A esterases. The A esterases of syngen 2 are more numerous than those in other syngens. Up to five different $A$ isozymes may occur in a single stock. Some of the A isozymes are common to several stocks. Others are unique to a particular stock. Some of the variations are shown in Fig. 5A,B. The B esterase of syngen 2 typically migrates to the cathode. Stock 305 has a variant form which migrates very slowly to the anode 


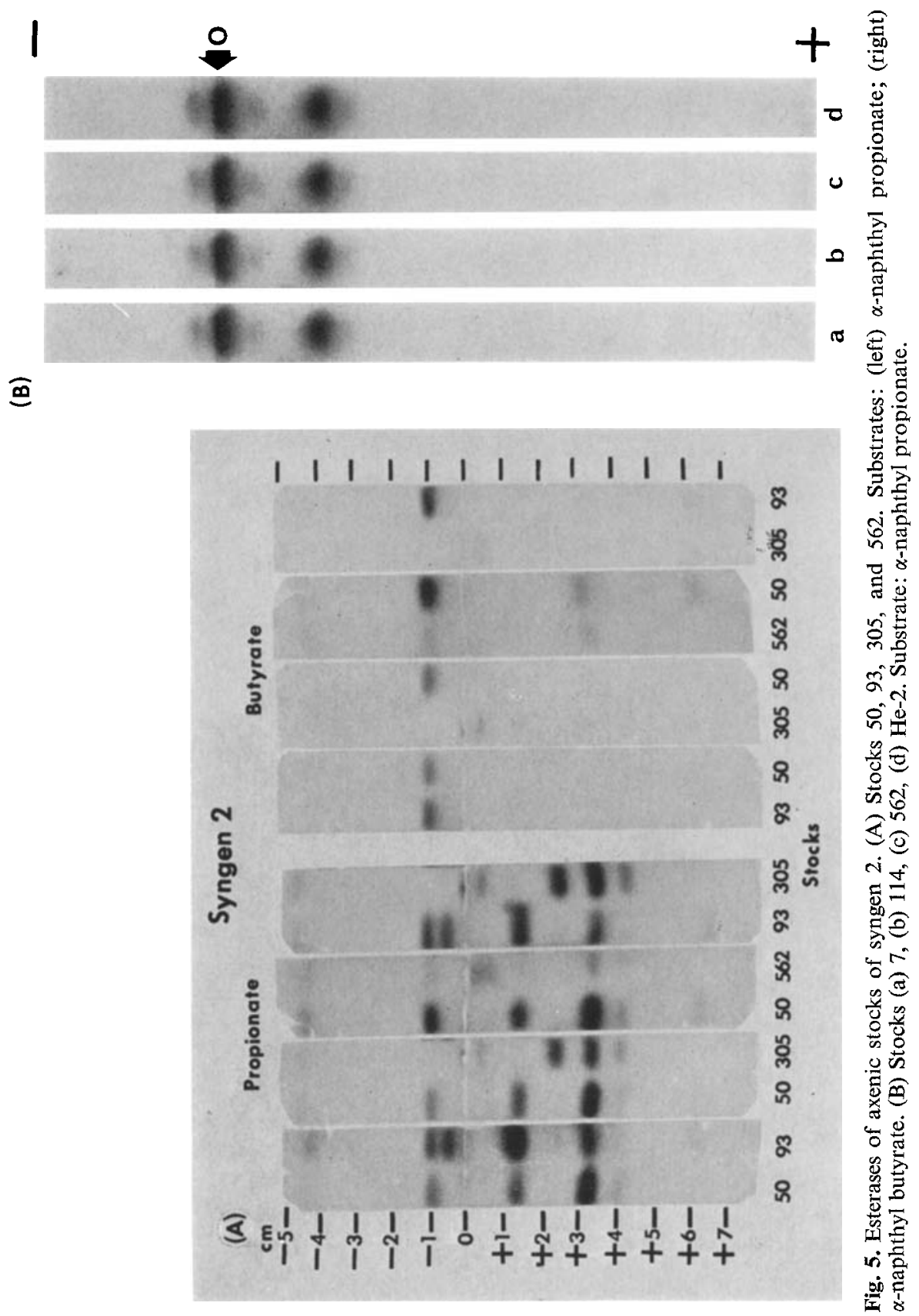




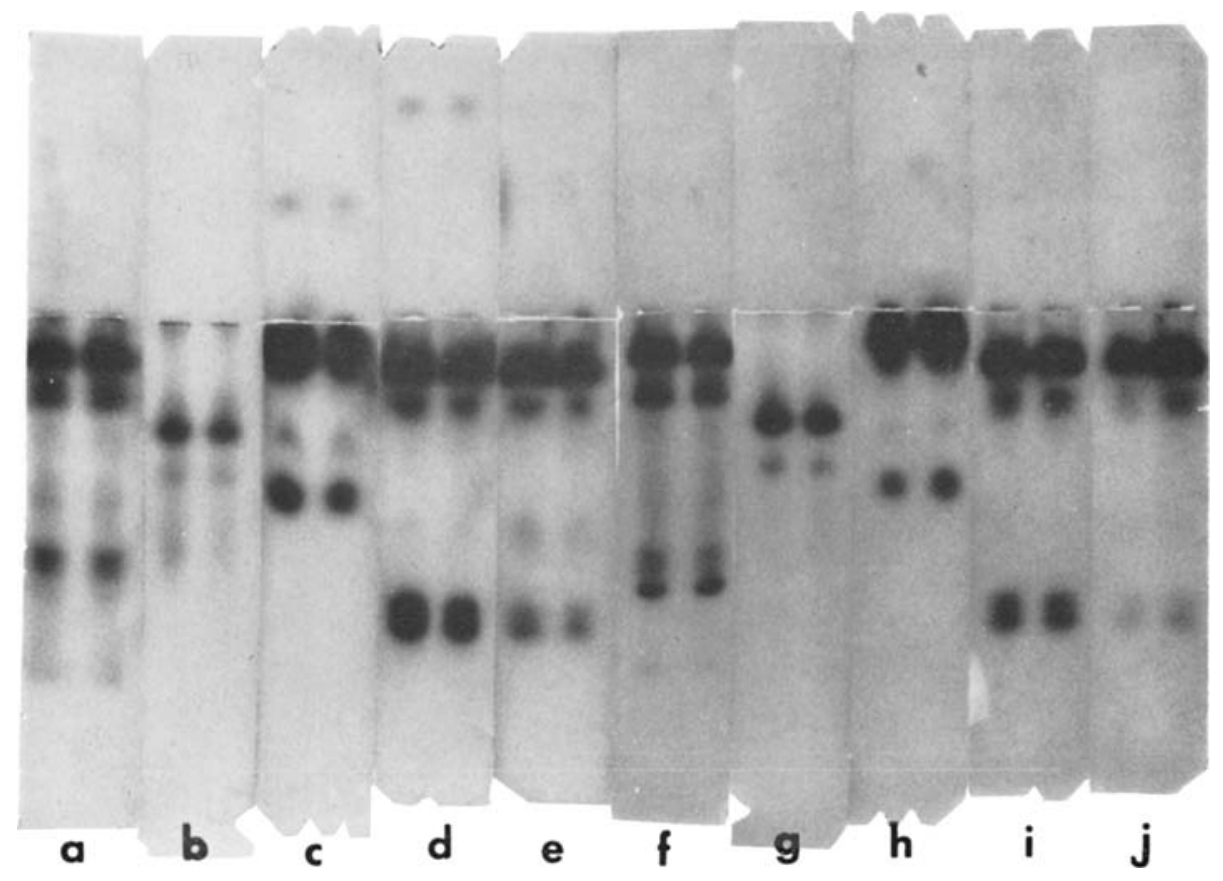

Fig. 6. Esterases of axenic stocks of syngen 8 . (a-e) Substrate: $\alpha$-naphthyl acetate. (f-j) Substrate: $\alpha$-naphthyl propionate. Stock (a) 131, (b) 137, (c) 299, (d) 130, (e) 138, (f) 131, (g) 137, (h) 299 , (i) 130 , (j) 138 .

(Fig. 5A). Thus, except for syngen 2, we conclude that intrasyngenic variation occurs rarely in $P$. aurelia. A similar conclusion was reached in a survey of the bacterized Indiana stocks (Allen et al., 1971). Here many more stocks could be screened, and variants were confined to syngen 2 with the exception of one in syngen 8 (stock 299) and one in syngen 4 (which may not have been a true variant but misclassified as to syngen).

The lack of intrasyngenic variation contrasts to the variations observed among syngens. These are diagrammed in Fig. 3. The four types of esterases (A, B, C, and D) occur in all of the syngens. Major variations affect types $\mathrm{A}, \mathrm{B}$, and the cathodal $\mathrm{C}$ esterase. Each type varies independently, suggesting that each type is specified by a different gene.

Studies on inhibitors strengthen this argument. No effect on any of the esterases was observed when sodium taurocholate $\left(10^{-2} \mathrm{M}\right)$ or $p$-chloromercuribenzoic acid $\left(10^{-3} \mathrm{M}\right)$ was incorporated into the incubation medium containing either substrate. However, differential inhibition was found with the inhibitor eserine sulfate. Moreover, the differential effects cut across syngen barriers. Fig. 7a,b shows that the A esterases are most sensitive to eserine sulfate $\left(10^{-3}\right.$ to $\left.10^{-4} \mathrm{M}\right)$. Higher concentrations of this inhibitor $\left(10^{-2} \mathrm{M}\right)$ also bring about the inhibition of the B esterases in different syngens (Fig. 7c). Types $\mathrm{C}$ and $\mathrm{D}$ are resistant to high concentrations of eserine 

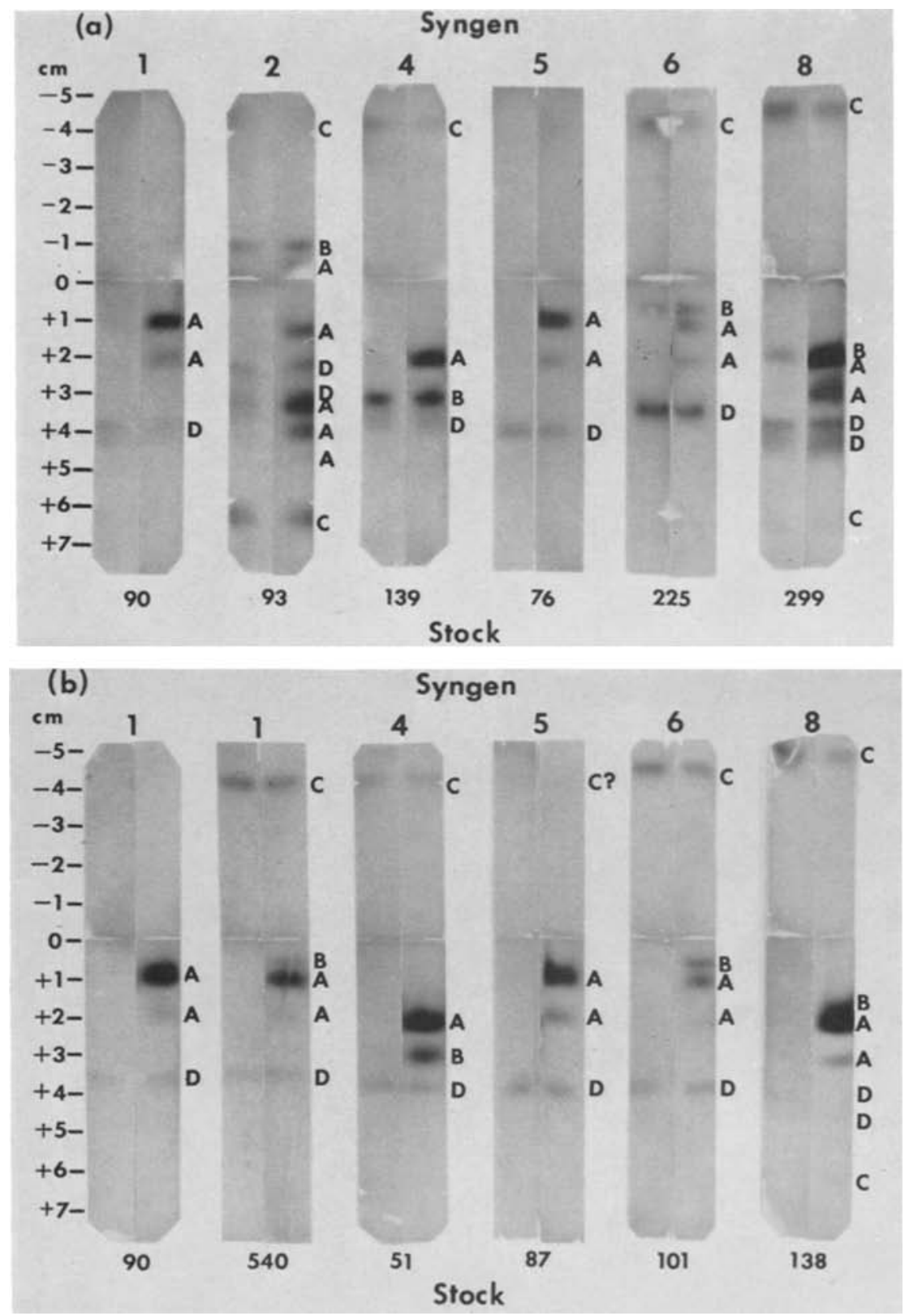

Fig. 7. Effect of the inhibitor eserine sulfate on the four types of esterases (A, B, C, and $D)$ in different stocks and syngens of $P$. aurelia. (a) $\alpha$-Naphthyl propionate and $10^{-3} \mathrm{M}$ eserine sulfate. (b) $\alpha$-Naphthyl propionate and $10^{-2}$ M eserine sulfate. (c) $\alpha$-Naphthyl butyrate and $10^{-2} \mathrm{M}$ eserine sulfate. (d) $\alpha$-Naphthyl butyrate and $10^{-1} \mathrm{M}$ eserine sulfate. Experimental gels are on left, control gels on right. Types of esterases are indicated to the right of control gels. Note inhibition of A esterases with $10^{-3} \mathrm{M}$ eserine sulfate in (a), inhibition of $B$ esterases with $10^{-2} \mathrm{M}$ eserine sulfate in (b) and (c), and resistance of $C$ and $\mathrm{D}$ esterases to $10^{-1} \mathrm{M}$ eserine sulfate in (d). Distances in migration are marked off in centimeters from the origin. Electrophoresis was carried out for $5 \mathrm{hr}$. 

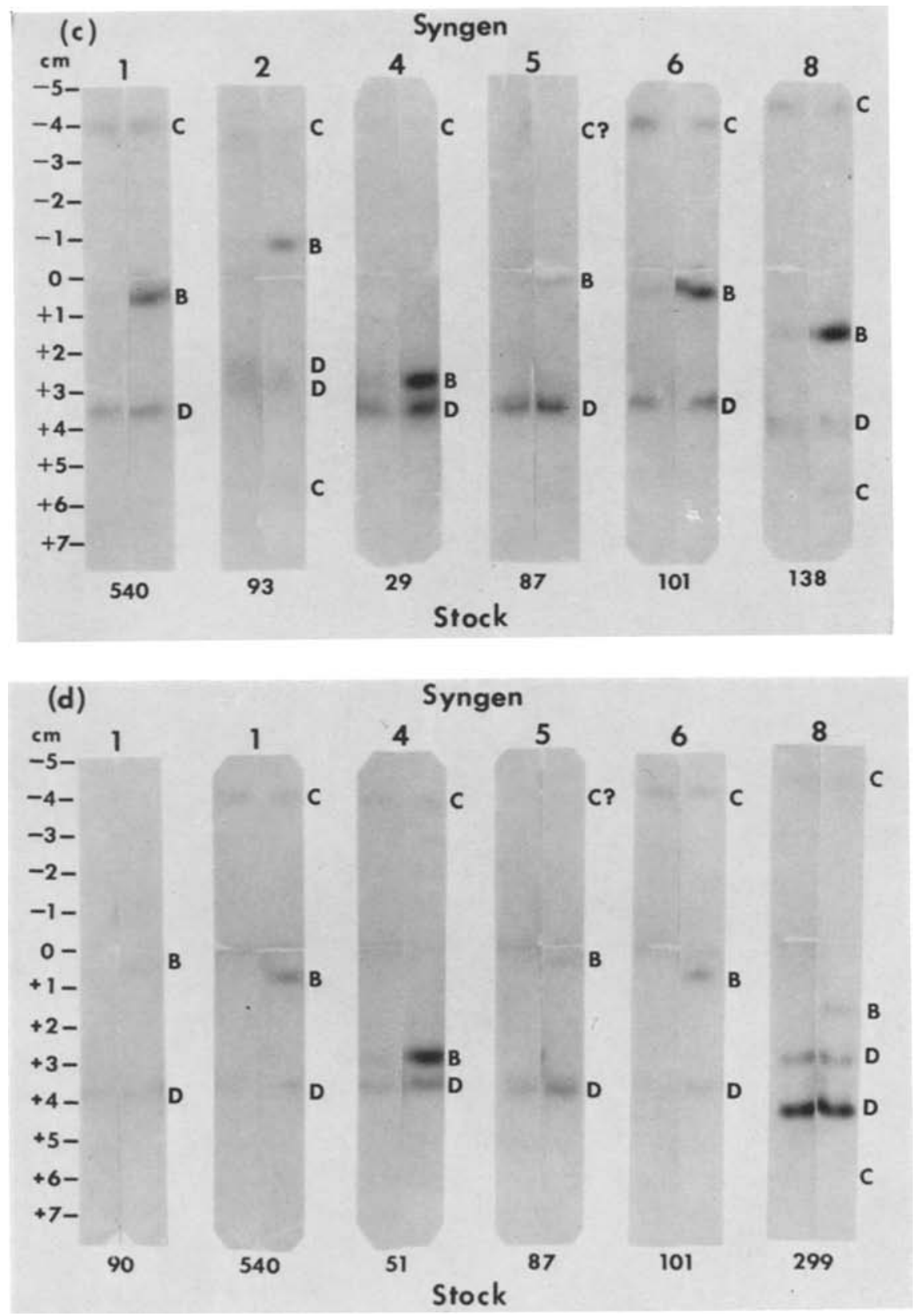

Fig. 7 (continued). 
$\left(10^{-1}\right.$ M) (Fig. 7 d). Thus, three of the four types of esterases can be distinguished in terms of their eserine sensitivity and ordered into the following series with respect to sensitivity: $A>B>C=D$. The significant fact is that this series applies to each type of esterase regardless of what syngen it is found in.

The Paramecium esterases differ from Tetrahymena esterases in their response to the other two inhibitors. T. pyriformis contains an A type esterase, sensitive to eserine sulfate $\left(10^{-4} \mathrm{M}\right)$. This is activated by sodium taurocholate $\left(10^{-2} \mathrm{M}\right)$. The A esterase of Paramecium is not, and therefore differs from Tetrahymena. Tetrahymena also contains a type of esterase specific for $\alpha$-naphthyl butyrate and it is inhibited by $p$-chloromercuribenzoic acid $\left(10^{-3} \mathrm{M}\right)$. This type of esterase apparently is not found in $P$. aurelia.

\section{Ordering of Syngen Variations}

Independent variation of esterase types $\mathrm{A}, \mathrm{B}$, and $\mathrm{C}$ occurs in different syngens (Figs. 3 and 4). Type $A$ is highly variable in syngen 2, and there appear to be several isozymes (Fig. 5A,B). Two A esterase isozymes are found in syngens 1, 5, 6, and 8, the more cathodal A esterase being more active. In syngen 6 , the A isozymes are weaker in activity. Syngen 4 appears to have a single $A$ esterase in axenic stocks. The set of isozymes is slowest in migration in syngens 1,5 , and 6 , and more rapid in syngens 4 and 8.

Type B occurs as a single isozyme and may occupy several different positions. In syngen 2 , it is usually cathodal in migration. In the others, it migrates to the anode and the syngen positions are as follows: 1 and 5, 6,8, and 4, in order of mobility.

Where present, the cathodal type $\mathrm{C}$ esterases are confined to a narrow zone in different syngens. Axenic stocks of syngens 1 and 5 usually lack cathodal $C$ esterase activity. Stock 540 without its killer particles is an exception in this respect (see Fig. 4c). A slow isozyme is found in syngens 2, 4, and 6, and stock 540 (syngen 1), a more rapid isozyme in syngen 8 . Anodal type $C$ esterases are confined to syngens 2 and 8. Intrasyngenic variation seems to occur in the anodal $C$ esterase of syngen 2 . The two members of the $\mathrm{C}$ doublet of syngen 8 vary in activity in different extracts of the same stock.

We would have no difficulty in keying an unknown stock to syngens 1 or $5,2,4,6$, and 8 , provided it were nonvariant. If variant, there would be difficulties. For example, stock 540 would be classified as syngen 6 rather than syngen 1. Differentiation of syngens 1 and 5 could not be made using bacterized stocks either. The others could be differentiated using bacterized stocks, but the syngen patterns are much clearer in axenic stocks. For example, the patterns of bacterized syngen 6 stocks are not very distinct from the patterns of bacterized syngens 1 or 5 , whereas the axenic patterns of syngens 1 or 5 and 6 are clearly distinct (see Fig. 4a,b). In fact, the information on axenic stocks was used to interpret the patterns of bacterized stocks! Thus, the same ordering of variations is achieved with the use of axenic stocks, but it is far easier to make the comparisons.

We hope we can extend the survey to axenic stocks from the remaining syngens. Some of these have rather similar esterases grown in bacteria. Grown axenically, better differentiation should be achieved. 


\section{DISCUSSION}

\section{Types of Esterases in Axenic Stocks}

There are four types of esterases in $P$. aurelia which are found in most of the axenic stocks surveyed so far. These types differ in substrate specificity and/or in their response to the inhibitor eserine sulfate. The three major types (A, B, and cathodal C) are found in axenic stocks of all the syngens examined so far. The data on bacterized stocks indicate that these major types are also present in the other syngens (Allen et al., 1971). Thus, these types appear to be distributed throughout all the syngens of $P$. aurelia. In addition to these major types of esterases, there are others. Some of these are restricted to certain syngens $(2,8)$. Others, such as the type $D$ esterases which vary even within the same stock, may vary between stocks either within or among syngens.

The differences in substrate specificity, sensitivity to eserine sulfate, and independent variation of the different types of esterases in different stocks suggest that there are several genes which specify esterases in $P$. aurelia. Breeding data indicate that single gene differences are involved for some of the variants within a syngen (Gibson, unpublished). The basis for variations among syngens cannot be determined by breeding analysis but relies upon the chemical characterization of the types of esterases. On this basis, different syngens have homologous enzymes, and we infer that this means there are homologous genes in different syngens. The minimum number is of the order 4-6. To establish homology, further chemical and physical analysis on purified enzymes will of course be necessary.

\section{Syngen Relationships}

If each of the three major types of esterases is coded by a different gene, then we can interpret the syngen variations in terms of differences in these three homologous genes. In other words, similarity in the electrophoretic migration of one type of esterase in stocks of different syngens implies that both syngens have a similar "allele". We suggest that some syngens have similar alleles for the A esterases and others for the $\mathrm{B}$ or $\mathrm{C}$ esterases. If each gene segregates independently, then we can examine the distribution of alleles for each type of esterase among the syngens and ask how different syngens are related.

Syngens 1 and 5 have identical esterases and thus appear to have similar genes. Tait (1970) also found that they had identical mitochondrial enzymes. Syngens 4 and 8 have similar A esterases but differ in their B and C esterases and hence in two out of the three esterase genes. Tait (1970) found that syngens 4 and 8 differed in three out of the five enzymes that he studied. Syngen 2 stocks differ from syngen 8 in all three esterases and thus in all three genes. Tait (1970) found that these syngens differed in four out of five other enzymes. Intersyngenic mating has been observed between syngens 1 and 5 and between syngens 4 and 8, but not between syngens 2 and 8 (Sonneborn, 1957). Thus, the enzyme genes appear to be somewhat more similar between syngens which show the mating reaction than those which do not.

Based on mating-type inheritance, Sonneborn (1957) suggested that there were 
major subgroups of syngens in $P$. aurelia which were of ancient evolutionary origin. The "A" group consisted of syngens 1, 3, 5, 9, and 11, the "B" group of syngens 2, 4, 6, $7,8,10,11$, and 14, and the "C" group of syngen 13 (Sonneborn 1957, 1958, 1966; Sonneborn et al., 1959; Rafalko and Sonneborn, 1959). Do the isozyme studies support this suggestion? The A esterases of syngens 2, 4, and 8 seem to depart more radically from those of other syngens $(1,5$, and 6$)$. But when we look at the other two esterases, these groupings begin to break up and different relationships among syngens appear. Other groupings among syngens can be made on the basis of mitochondrial enzymes (Tait, 1970). If each type of character results in a different grouping of the syngens, it does not appear that there are major cleavages within the species complex.

One goal of the isozyme technique is to attempt to measure evolutionary distances between syngens. If differences between syngens can be quantitated, then we can try to place the syngens in a matrix with respect to one another in terms of distance. We have made such an effort with the results so far obtained on the esterases and on Tait's mitochondrial enzymes. Different matrices are generated. Either the data are incomplete (which is true for the esterases so far as the survey of axenic stocks is concerned) or our method is at fault and we need to think through other ways of quantitating the data. Until we have completed the survey of axenic stocks, we will therefore defer presenting our efforts in quantitation.

\section{Differences Among Stocks Within a Syngen}

Intrasyngenic variation in the esterases is rare in $P$. aurelia, with the exception of syngen 2 . We have surveyed fewer axenic than bacterized stocks, but, in general, the differences among stocks within a syngen may be even less in axenic medium. There may be variations due to differences in gene expression, but these seem limited to the $D$ type of esterases and perhaps to some of the $C$ esterases. Genes affecting the activity of certain A and C esterases occur in some of the stocks (Gibson, unpublished).

A few intrasyngenic variants were observed by Tait (1970). The majority of these seem to be of a type different from those seen among syngens. Instead of a single zone of activity in the gel, these variants had multiple zones. Whether these are "primary" or "secondary" isozymes according to the terminology used by Shaw (1969) has apparently not yet been determined.

The frequency of intrasyngenic variants in different syngens is shown in Table II for the $A$ and $B$ esterases. Here, we have pooled the information from both axenic and bacterized stocks. If we disregard the syngen 2 variants, we obtain a frequency of $1.9 \%(3 / 158)$ for both esterases. This is slightly higher than the frequency of variants of four enzymes observed by Tait, since we obtain a value of $0.72 \%(4 / 536)$ from his pooled data. If we include syngen 2 , the frequency of his variants is not raised $(0.74 \%$ $7 / 976)$, but the frequency of esterase variants is $(4.7 \%-9 / 192)$. Syngen 2 by itself has a very high frequency of variants $(18 \%$ ), most of which are the A type. Syngen 2 shows greater variation for the esterases than for other enzymes. All other syngens show a low frequency of variation, similar to the degree of variation observed by Tait for his enzymes. 
Table II. Number of Variant Types/Total Number of Stocks Surveyed per Syngen for A and B Esterases

\begin{tabular}{cll}
\hline Syngen $^{a}$ & \multicolumn{1}{c}{ A } & \multicolumn{1}{c}{ B } \\
\hline 1 & $0 / 20$ & $1 / 20$ \\
2 & $5 / 17$ & $1 / 17$ \\
3 & $0 / 5$ & $0 / 5$ \\
4 & $0 / 15^{b}$ & $0 / 15^{b}$ \\
5 & $0 / 7$ & $0 / 7$ \\
6 & $0 / 5$ & $0 / 5$ \\
7 & $0 / 4$ & $0 / 4$ \\
8 & $2 / 13^{c}$ & $0 / 13^{c}$ \\
9 & $0 / 4$ & $0 / 4$ \\
12 & $0 / 3$ & $0 / 3$ \\
13 & $0 / 3$ & $0 / 3$ \\
Total & $7 / 96$ & $2 / 96$ \\
Total-Syngen 2 & $2 / 79$ & $1 / 79$ \\
& & \\
\hline
\end{tabular}

${ }^{a}$ Only one stock was surveyed in syngens 10,11 , and 14 .

${ }^{b}$ A questionable variant (with syngen 8 esterases) is not included here.

${ }^{c}$ UEA and Indiana $299 \neq$ van Wagtendonk's 299 and are therefore considered to be different stocks although both appear to be syngen 8 on basis of $\mathrm{B}, \mathrm{C}$ cathodal and $C$ anodal esterases specific for 8 .

\section{Why Is Intrasyngenic Variation So Low?}

The observed frequency of intrasyngenic variation for both the esterases and Tait's enzymes, four of which were mitochondrial, was much lower than expected. Why was this unexpected?

First, cytogenetic studies suggest local diversification of stocks and barriers to gene flow. The micronuclear chromosome numbers vary in different stocks of syngens 1 and 4 and differences in chromosome number were found to be correlated with low fertility in crosses (Kościuszko, 1965; Dippell, 1954). Crosses between stocks from the same populations were found to be highly fertile, while those between stocks from different populations and with different chromosome numbers were much less viable. A direct correlation was found in one study in which the greater the departure in chromosome numbers the less the viability of the $F_{2}$ (Kościuszko, 1965). Such observations would predict that stocks in the same syngen but from different parts of the world would accumulate different mutations and these would be expressed because of homozygosity resulting from autogamy. We would expect as a result of genetic drift or natural selection operating in different ways on these populations, that they would diverge and become highly polymorphic.

Considerable polymorphism does seem to occur for the surface antigens. Such studies have been made for syngen 1 (Beale, 1954) and for syngen 9 (Pringle, 1956; 
Pringle and Beale, 1960). Wild populations were surveyed, and several alleles were identified at different antigen loci in these populations. In an extensive analysis of a single population scored over several years, little departure from a particular gene frequency was observed, although the frequency of heterozygotes was lower than expected (Pringle and Beale, 1960). It was not possible to distinguish between the hypothesis of neutral alleles and selective advantage of the heterozygote.

$P$. aurelia can undergo conjugation in which pairs of animals exchange genes, or a single animal can undergo autogamy and become homozygous. We do not know how frequently animals conjugate in nature since the density of animals appears to be low (Pringle and Beale, 1960).

We do know that the same pond can contain several syngens (Pringle, 1956). As many as four syngens were found in a pond at Hethersett near Norwich, England (Gibson and Hewitt, unpublished). In the Hethersett Pond, populations of syngens 2 and 9 were found to be highly polymorphic for their antigens. The esterases were similar in all the animals examined in syngen 9, but at least six different variations were found in the syngen 2 population. All of these were variants of the A type of esterase.

These observations suggest that selection varies in intensity for different characters and in different syngens. Syngen 2 is an exception. Within this syngen, there is considerable variation for the esterases although not for the mitochondrial enzymes. But in all the other syngens the enzymes appear to be under stringent selection, and this pertains to both the esterases and the mitochondrial enzymes.

Why is this so? If the enzymes were essential enzymes, little variation might be expected. Yet, syngen differences occur, and whether a particular allele is established within a syngen does not seem to matter-if it is present in different syngens. Why is it then that it is maintained in all stocks of a syngen regardless of their geographic location? The answer to this question hinges upon an understanding of the broader question of the effect of the change in net charge of an enzyme on its kinetics and placement and integration within the cell. Are charge changes without effect and therefore selectively "neutral" or should they not be considered in terms of the cell as a whole and thus subject to selection?

How can we reconcile cytogenetic differences among stocks and enzyme constancy? Perhaps this is reconciled by considering the fact that nuclear dimorphism occurs in $P$. aurelia and we do not know if all the micronuclear genome actually is represented in the macronucleus. This is the nucleus concerned with gene expression. If there were selection for expression of only part of the micronuclear genome in the developing macronucleus, then variations in micronuclear chromosomes might not be reflected in differences in enzymes.

Are certain characters more variable in the stocks of $P$. aurelia than others? If so, which characters vary and which tend to be conserved? Do surface characters (antigens, cortical architecture, etc.) tend to vary more extensively than nonsurface characters such as enzymes?

In its natural habitat, $P$. aurelia is bathed in a sea of bacteria which it consumes for food. In some instances, the bacteria become incorporated into the Paramecium in a symbiotic relationship. Some seven different types of bacterial symbionts have been 
described (Beale et al., 1969). These are found in particular stocks of certain syngens. Is it possible that the bacteria or symbionts introduce variability into the Paramecium by supplying certain enzymes? Perhaps as a result of the presence of bacterial enzymes, many host enzymes are eliminated during evolution or are repressed.

The symbionts are not randomly distributed within the syngens (Beale et al., 1969). Syngen 2 has five of the seven symbionts so far described. No symbionts have been found in syngen 9 . If our theory were correct, we could expect enzyme variation to be more extensive in syngen 9 than in syngen 2 . Indeed, the observations are if anything to the contrary. At least in the case of the esterases, they seem to vary more extensively in syngen 2 than in syngen 9 . Perhaps instead of eliminating host enzymes, the presence of symbionts results in the switching on of host genes. This would then lead to a positive correlation between the presence of symbionts and increased variability in the repertoire of host enzymes.

We do not have any answers for the lack of variation of enzymes within most syngens. Nor why syngen 2 is exceptional for its esterases. More problems are raised than solved! We do feel that future studies should be directed at determining in which stocks and in which syngens variations do occur and whether the existence of variation is correlated in any way with the presence or absence of symbionts.

\section{Comparison of $P$. aurelia and $T$, pyriformis}

$P$. aurelia differs from $T$. pyriformis in the extent of enzyme variation within a syngen. It is extremely rare in Paramecium but very common in Tetrahymena. Indeed, it occurs to such a high degree in Tetrahymena even within a single clone that it is difficult to compare syngens in terms of enzyme variations. Why is there such a difference between these groups of ciliated protozoa?

Both ciliates have two types of nuclei (see Raikov, 1969, for a review of the macronucleus). We do not really know how the genetic material is organized within the macronucleus of either ciliate, although there are hypotheses. There may be diploid subnuclei (Nanney, 1964) or there may be a looser type of arrangement of the genes (Allen and Gibson, 1971). We do not know if the macronuclear elements are differently organized in the two ciliates. They could differ in important ways which result in different ways of controlling gene expression. We do know that the base composition of DNA varies over a range of $8 \%$ in different syngens of Tetrahymena but that it does not seem to vary by more than 1 or $2 \%$ in different syngens of Paramecium when grown axenically (Allen and Gibson, unpublished).

The two groups of ciliated protozoa also differ in the incidence of symbiotic bacteria. Symbionts of a number of different types are found in some $30 \%$ of the stocks of $P$. aurelia when first recovered from nature (quoted from Sonneborn, 1956, in Beale et al., 1969). Although van Wagtendonk and Soldo (1965) record the presence of a symbiont in Tetrahymena sp., to our knowledge symbionts have not been reported in T. pyriformis. However, this difference could be technical since nearly all the strains of Tetrahymena have been collected through antibiotic screens; antibiotic screens are not used in the Paramecium collections, and these antibiotics readily remove the symbionts from Paramecium. 
Paramecium also differs from Tetrahymena in its potential for inbreeding. Paramecium can undergo autogamy, while Tetrahymena cannot. Thus, Tetrahymena should tend to be more of an outbreeder than Paramecium. However, the degree of outbreeding depends on its system of mating-type inheritance, and in each group there are differences among syngens in mating-type inheritance that temper the effects of differences in breeding behavior between the species complexes (Sonneborn, 1957). In general, we might expect to find a greater degree of heterozygosity in natural populations of Tetrahymena than in Paramecium. Some of the enzyme variation seen in Tetrahymena could then be due to heterozygosity per se. On the other hand, inbreeding should promote greater differentiation of local populations and we might expect to observe more polymorphism among different populations in the case of Paramecium than in Tetrahymena.

We feel that fundamental differences in macronuclear organization, gene expression, possession of symbionts, and breeding systems are factors to be taken into consideration in attempting to account for the differences in intrasyngenic variation in enzymes between Paramecium and Tetrahymena. We can partly state that selective forces in the two groups of organisms must differ during evolution. But we do not know which of the various factors are more important, what the selective forces are, or how they operate to bring about the differences.

\section{ACKNOWLEDGMENTS}

We would like to thank Dr. W. J. van Wagtendonk (University of Miami School of Medicine) for sending us the axenic stocks indicated. Bacterized stocks were obtained from N. G. Hairston (University of Michigan) and T. M. Sonneborn (Indiana University). The UEA stocks were obtained from G. H. Beale (University of Edinburgh). The patient assistance of Alan Cavill and Norman Martin (University of East Anglia) and Patricia A. Golembiewski, Patricia H. T. Lee, and Frances J. Malinoff (University of Michigan) is gratefully acknowledged.

\section{REFERENCES}

Allen, S. L., and Gibson, I. (1971). Genetics of Tetrahymena. In Elliott, A. M. (ed.), Biology of Tetrahymena, Appleton, Century, Crofts, Inc., New York (in press).

Allen, S. L., and Weremiuk, S. L. (1971). Intersyngenic variations in the esterases and acid phosphatases of Tetrahymena pyriformis. Biochem. Genet. 5: 119.

Allen, S. L., Byrne, B. C., and Cronkite, D. L. (1971). Intersyngenic variations in the esterases of bacterized Paramecium aurelia. Biochem. Genet. 5: 135.

Beale, G. H. (1954). The Genetics of Paramecium aurelia, Cambridge University Press, London and New York, $179 \mathrm{pp}$.

Beale, G. H., Jurand, A., and Preer, J. R. (1969). The classes of endosymbiont of Paramecium aurelia. J. Cell Sci. 5: 65 .

Dippell, R. V. (1954). A preliminary report on the chromosomal constitution of certain variety 4 races of Paramecium aurelia. Caryologia 6 (suppl.): 1109.

Dryl, S. (1959). Antigenic transformation in Paramecium aurelia after homologous antiserum treatment during autogamy and conjugation. J. Protozool. 6 (suppl.): 25 (abst.).

Kościuszko, H. (1965). Karyologic and genetic investigations of syngen 1 of Paramecium aurelia. Folia Biol. 13: 339. 
Nanney, D. L. (1964). Macronuclear differentiation and subnuclear assortment in ciliates. In Locke, M. (ed.), The Role of Chromosomes in Development, Academic Press, New York, pp. 253-273.

Pringle, C. R. (1956). Antigenic variation in Paramecium aurelia, variety 9. Z. Induktive AbstammungsVererbungslchre 87: 421.

Pringle, C. R., and Beale, G. H. (1960). Antigenic polymorphism in a wild population of Paramecium aurelia. Genet. Res. Camb. 1: 62.

Rafalko, M., and Sonneborn, T. M. (1959). A new syngen (13) of Paramecium aurelia consisting of stocks from Mexico, France and Madagascar. J. Protozool. 6 (suppl.): 30 (abst.).

Raikov, I. B. (1969). The macronucleus of ciliates. In Chen, T.-T. (ed.), Research in Protozoology, Vol. 3, Pergamon Press, New York, pp. 1-128.

Rowe, E., Gibson, I., and Cavill, A. (1971). The effects of growth conditions on the esterases of Paramecium aurelia. Biochem. Genet, 5: 151.

Shaw, C. R. (1969). Isozymes: Classification, frequency and significance. Intern. Rev. Cytol. $25: 297$.

Soldo, A. T., Godoy, G. A., and van Wagtendonk, W. J. (1966). Growth of particle-bearing and particle-free Paramecium aurelia in axenic culture. J. Protozool. 13: 492.

Sonneborn, T. M. (1957). Breeding systems, reproductive methods and species problems in protozoa. In Mayr, E. (ed.), The Species Problem, Am. Assoc. Adv. Sci. Symp., Washington, D.C., pp. 155324.

Sonneborn, T. M. (1958). Classification of syngens of the Paramecium aurelia-multimicronucleatum complex. J. Protozool. 5 (suppl.): 17 (abst.).

Sonneborn, T. M. (1966). A non-conformist genetic system in Paramecium aurelia. Am. Zoologist 6: 589 (abst.).

Sonneborn, T. M., Schneller, M. V., Mueller, J. A., and Holzman, H. E. (1959). Extensions of the ranges of certain syngens of Paramecium aurelia. J. Protozool. 6 (suppl.): 31 (abst.).

Tait, A. (1970). Enzyme variation between syngens in Paramecium aurelia. Biochem. Genet. $4: 461$.

van Wagtendonk, W. J., and Soldo, A. T. (1965). Endosymbiotes of ciliated protozoa. In Progress in Protozoology, Excerpta Medica Foundation, Internat. Congress Series No. 91, p. 244.

van Wagtendonk, W. J., Goldman, P. H., and Smith, W. L. (1970). The axenic culture of strains of the various syngens of Paramecium aurelia. J. Protozool. 17: 389. 